\title{
Iowans in National Statuary Hall
}

Absence of essential data as to representative Iowans officially designated and assigned to positions in the National Statuary Hall at Washington, D.C., recently occasioned research upon this subject by the AnNaLs editor, the results of which merit definite recording.

It was by an act of congress on July 2, 1864, that the president of the United States was authorized to invite all the states to provide statues, not to exceed two in each state, "of deceased persons who had been citizens thereof and illustrious for their historic renown or for distinguished civic or military service," to make such designation and present to the government these marble or bronze statues.

In line with this action the old house chamber in the national capitol was reserved for this purpose and renamed the National Statuary Hall. It is a semi-circular room 96 feet in diameter, extended on the flat side by a colonnaded bay. During occupancy from 1807 to 1857 as the house of representatives chamber, the accoustics were found to be faulty, and to smother reverberations great curtains were hung between the columns on the south side:

In this historic hall Madison and Monroe were inaugurated presidents. Here John Quincy Adams was elected president, and here this aged ex-president was stricken with paralysis during a roll call in 1848 , dying at his post of duty, a metal plate in the floor marking the spot where he fell. Due to over-crowding, some of the numerous statues of statesmen and other notables were removed later to the Hall of Columns, which serves as a monumental foyer to the south portal of the capitol, also to the several principal floor corridors and elsewhere.

Compliance by Iowa with the president's request was somewhat tardy. Finally provision was made at separate times for the statues of Samuel J. Kirkwood and James Harlan, stalwart early Iowans, to repre- 
sent the state in bronze in this capacity, funds being appropriated for that purpose. The Thirty-first General Assembly authorized the moulding of the statue for Kirkwood, and Governor Cummins signed the act April 5, 1906. The Thirty-second General Assembly followed suit by naming James Harlan for the second honor, the signing of this act, also by Governor Cummins, occurring March 20, 1907, the operation of the amendment to the state constitution providing for biennial elections bringing the two sessions of the legislature in consecutive years. No other Iowans were seriously considered for these honors, then regarded so well deserved by these two distinguished Hawkeye statesmen.

Kirkwood's outstanding service to the state and nation was acknowledged, beginning with aggressive leadership in the Iowa senate in 1856, then as governor in 1860-64 during the Civil war period, and again in 1875-77, following his term in the United States senate in 1865-67. He was described by James G. Blaine as "a man of truth, courage and devoted to love of country; distinguished for comprehensive intelligence, for clear foresight, for persuasive speech, for spotless integrity, for thorough acquaintance with the people; he was a model of efficiency."

When the legislature voted to issue $\$ 800,000$ in bonds to carry on Iowa's part in the war, only $\$ 300,000$ was expended, so strict and careful was his practice of economy, as the state's executive. Favoring the nomination and election of Lincoln, he was urged by John A. Kasson, though he did not need the letter of the latter, saying: "Pray be at Chicago, if possible, to aid and influence the indiscreet by your counsel." Taking his seat first in the United States senate in 1865, he succeeded James Harlan, who had resigned to take a seat in President Lincoln's cabinet as secretary of the Interior. Following his last term in the United States senate, 1877-81, he was appointed by President Garfield as secretary of the Interior, serving only a short time 
as such in 1881-82, and then resigned. The bronze statue of him standing in the National Statuary Hall is the work an an Iowa sculptress-Vinnie Ream Hoxie.

The high tribute paid to the memory of James Harlan, likewise was well deserved. First prominent in Iowa as an educator, he was elected as its first superintendent of public instruction over Charles Mason, the first chief justice of the supreme court. $\mathrm{He}$ at once put into operation a sound and efficient school system, and established wise procedure in the handling of the state's school lands and educational funds.

Mr. Harlan was president of Iowa Wesleyan university at Mount Pleasant, in 1853; served as United States senator from Iowa from 1855 to 1865 , and returned to the senate from the president's cabinet, serving from 1867-73; appointed by President Lincoln as secretary of the Interior just prior to the assasination of the latter, and his daughter Mary married Robert T. Lincoln. The statue provided as a memorial to the public life of Senator Harlan was first executed in clay and then in bronze, by Nellie V. Walker of Chicago, and occupying its place at the national capitol, reflects the signal honor conferred by his state.

Art is said to look to posterity for its approval. Should these statues endure, citizens of the remote future, if interested in these outstanding representations of the great men of Iowa and other commonwealths, will search the records and literature of the state's past, as well as the nation, wherein these men, with their own hands and deeds wrote the measure of their greatness. These statues, like monuments erected by admiring neighbors and a grateful people, symbolize the tributes of a state in recognition of the eminence of the attainments of those thus honored. 
Copyright of Annals of Iowa is the property of State of Iowa, by \& through the State Historical Society of Iowa and its content may not be copied or emailed to multiple sites or posted to a listserv without the copyright holder's express written permission. However, users may print, download, or email articles for individual use. 